\title{
Ceza infaz kurumlarında sağlık hizmetlerinin verilmesi
}

\section{Providing health care services in penitentiaries}

\author{
Mehmet Ali Tokgöz' , Hilal Tokgöz², Yunus Emre Çakır³ \\ ${ }^{1}$ Ankara Ceza İnfaz Kurumları Kampüs Devlet Hastanesi, Ankara \\ ${ }^{2}$ Ankara Üniversitesi Tıp Fakültesi Adli Tıp Anabilim Dalı, Ankara \\ ${ }^{3}$ Istanbul Adli Tıp Kurumu Başkanlığı, İstanbul
}

Tutuklu ve hükümlülerin sağlık bakımı, tıbbi, mali ve güvenlik konularını içeren karmaşık bir durumdur; dolayısıyla, genel nüfustan niteliksel ve niceliksel olarak farklıdır. Yapılan bir çalışmada, tutuklu ve hükümlülerin \%65-81'inin bir veya daha fazla sağlık probleminden muzdarip olduğu bildirilmiştir. Tutuklu ve hükümlünün muayenesine makul bir zaman ayırmalı, muayene notları ve tedavi kararı özenli bir şekilde, UYAP (Ulusal Yargı Ağı Projesi) sistemine de işlenen, şahsi sağlık dosyasına ayrıntılı olarak not düşülmelidir. Kontrol muayenesi için yeniden çağırılacaksa veya girişimsel bir işlem planlandıysa tarih net bir şekilde yine sağlık dosyasına yazılmalıdır. Ülkemizde yapılan bir çalışmada tutuklu ve hükümlülerin acil servise başvuru nedenleri incelenmiş ve \%15,6'sının spor yaralanmalarına bağlı olduğu ve spor yaralanmalarının acil servise en sık başvuru nedeni olduğu bildirilmiştir. Tutuklu ve hükümlülerin tedavisine karar verirken, cezaevinin sosyal ve fiziki koşulları da kararda etkili olmalıdır. Cezaevinde hastaların çoğunlukla kendi başına kişisel bakımını yapması gerektiği (bakım veren eksikliği) ve uygun fiziki şartların sağlanmasında zorlukların olduğu (klozet tarzında tuvalet yokluğu gibi) bilinmelidir. Bu nedenle, özellikle alt ekstremite problemleri ile gelen tutuklu ve hükümlülerin, eğer tıbbi olarak imkân dâhilinde ise, bir an önce mobilize edilmesini sağlayacak tedavilerin tercih edilmesi uygundur. Cezaevlerinde yapılacak keşif çalışmaları ile, mevcut alt yapı ve insan gücünün doğru şekilde yönlendirilmesi, daha etkili ve verimli bir sağlık hizmeti verilmesi sağlanacaktır.

Anahtar sözcükler: ceza infaz kurumları; tutuklu-hükümlü sağlık hizmetleri; Türkiye'de mahkum sağlığı
Health care of detainees and convicts is a complex situation involving medical, financial and security issues. It is qualitatively and quantitatively different from general population. It was reported that $65-81 \%$ of detainees and convicts suffer from one or more health problems. A reasonable time should be allocated to examination of detainees and convicts, and examination notes and treatment decision should be carefully noted in his personal health file, which is also processed in the "UYAP" (National Judicial Network Project) system. If patient is recalled for the control examination or an interventional procedure is planned, date have to be clearly written in personal health file. In a study which was conducted in our country, the reasons for the application of detainees and convicts to emergency were investigated and it was reported that $15.6 \%$ of them were due to sports injuries, and it was the most common reason for referring to emergency department. Social and physical conditions of penitentiaries should be a part of decision for treatment decision of detainees and convicts. It should be noted that patients in penitentiaries have to take care of themselves (lack of caregivers) and that there are difficulties in providing appropriate physical conditions (such as absence of proper toilet facilities). Especially detainees and convicts who suffer from lower extremity problems should be treated most appropriately for immediate mobilization. Surveillance studies to be carried out in penitentiaries can ensure that existing infrastructure and manpower are guided correctly, and that more effective and efficient health service is provided.

Key words: penitentiaries, health care services for detainees and convicts, the health of prisoners in Turkey
T utuklu ve hükümlülerin sağlık bakımı, tıbbi, mali ve güvenlik konularını içeren karmaşık bir durumdur ve dolayısıyla genel nüfustan niteliksel ve niceliksel olarak farklıdır. ${ }^{[1]}$ Birleşmiş Milletler kararına göre, tüm tutuklu ve hükümlüler yeterli sağlık hizmetine erişme hakkına sahiptir. ${ }^{[2]}$ Dünya çapında cezaevi nüfusu son on yılda önemli ölçüde artmıştır. Bu artış ve cezaevi koşulları nedeniyle, tutuklu ve hükümlüler topluma kıyasla sağlığa erişim konusunda daha fazla sorun yaşamaktadır. ${ }^{[3-5]}$ Buna ek olarak; çok sayıda çalışma, tutuklu ve hükümlülerin bulaşıcı ve fiziksel hastalıklar için topluma kıyasla daha yüksek riskli olduğunu göstermektedir. ${ }^{[6-8]}$ Yapılan bir çalışmada, tutuklu ve hükümlülerin \%65-81'inin bir veya daha fazla sağlık probleminden muzdarip olduğu bildirilmiştir. ${ }^{[9]}$

- İletişim adresi: Dr. Mehmet Ali Tokgöz, Adalet Mah., Ankara Ceza İnfaz Kurumları Kampüs Devlet Hastanesi, Adalet Cd., 06946 Sincan, Ankara Tel: 0554 - 8738551 e-posta: m.alitokgoz@gmail.com

- Geliș tarihi: 9 Ekim $2019 \quad$ Kabul tarihi: 11 Kasım 2019 
Ülkemizde Adalet Bakanlığı verilerine göre iki yüz altmış bin (100.000 nüfus için 318 kişi) tutuklu ve hükümlü vardır. Bu sayının \%4,2'sini kadınlar ve \%1,2'sini on sekiz yaş altı kişiler oluşturmaktadır. ${ }^{[10]}$ Ceza infaz kurumlarında bulunan tutuklu ve hükümlülerin beden ve ruh sağlığının korunması ile muayene ve tedavi başta olmak üzere sağlık hizmetlerinden yararlandırılması devletin ve dolayısıyla ceza infaz kurumu idaresinin sorumluluğu altındadır.

\section{ÜLKEMIZDE MEVCUT DURUM}

Tutuklu ve hükümlülerin birinci basamak muayene ve tedavileri aile hekimleri tarafından yapılmaktadır. Hükümlü ve tutuklular ile personel ve ailelerinin toplam nüfusu 5000'i geçen ceza infaz kurumlarında sunulan sağlık hizmetleri, Sağlık Bakanlığı'na bağlı olarak faaliyet gösteren ve cezaevi kampüsü içerisindeki hastanelerde verilmektedir. Ülkemizde AnkaraSincan, İstanbul-Silivri, İstanbul-Maltepe ve İzmirAliağa Ceza İnfaz Kurumları bünyesinde bulunan dört adet kampüs hastanesi vardır. ${ }^{[11]}$

Kampüs dışı hastaneye sevki zorunlu görülen hükümlü veya tutukluların hastanelerdeki muayene ve tedavileri, en yakın Devlet veya Üniversite Hastanesinin hükümlü koğuşlarında ve firara karşı engellerin bulunduğu muhafazalı odalarda yapılır. Jandarma muayene esnasında oda dışında bulunur ve gerekli güvenlik tedbirlerini alır. Doktorun yazılı olarak talep etmesi halinde, muayene odasında güvenliği jandarma sağlar. Eğer sağlık tesisinde muhafazalı oda yoksa jandarma muayene odası içinde bulunur ve doktorla hasta arasında geçecek konuşmaları duymayacak uzaklıkta koruma tedbirini alır.

Ceza İnfaz Kurumlarının Yönetimi ile Ceza ve Güvenlik Tedbirlerinin İnfazı Hakkında Tüzük'ün 155 maddesi gereğince kelepçe ve bedensel hareketleri kısıtlayıcı araçlar çocuk hükümlülerde kullanılmamakta, erişkin kapalı cezaevinde kalan tutuklu ve hükümlülerde ise cezaevinden muayene odasının güvenliği sağlanana kadar geçen sevk süresinde kaçmayı veya kaçırılmayı engellemek amacıyla bağlı tutulmaktadır. Muayene odasında ise bu konuda yetki hekime bırakılmakta ve aynı tüzükte "Kelepçe ve bedensel hareketleri kısıtlayıcı araçlar'ın kurum revirinde veya sağlık kuruluşunda hükümlü hakkında uygulanacak muayene, teşhis ve tedavi sırasında, muayene, teşhis ve tedavi işlemlerinin güvenli bir şekilde yerine getirilmesi için zorunlu görülmesi hâlinde cezaevi tabibi veya hekimin talep ve gözetiminde kullanılabilir." hükmü yer almaktadır. Yine kişinin kendisine veya başkalarına zarar vermesine veya eşyayı tahrip etmesine engel olmak için kurum en üst amirinin emriyle kelepçe kullanılabilir. ${ }^{[12]}$
Zorlayıcı araçların muayene sırasında kullanımı konusunda sorumluluğu 5275 sayılı ceza ve güvenlik tedbirlerinin infazı hakkında kanunun 50. maddesi de yine hekime vermektedir. Bu gereçler hekimin talimat ve gözetiminde olmak üzere tıbbî nedenlerle kullanılabilir. ${ }^{[13]}$

Hastaneye sevk edilen hükümlü ve tutuklular, yatarak tedavi edilmeleri gerektiği takdirde, hükümlü koğuşu bulunan hastanelere yönlendirilirler. Hastanede hükümlü koğuşu olmadığı takdirde, jandarma tarafından gerekli güvenlik tedbirleri alınarak oluşturulacak geçici hükümlü koğuşlarında tedavileri yapılmaktadır. Tedaviyi yapan hekimin raporuyla zorunlu olduğunun bildirilmesi hâlinde, hükümlü koğuşunda yatarak tedavileri yapılan hükümlü ve tutukluların yanında eşi, annesi, babası, kardeşi, çocuğu, bunların olmaması hâlinde Cumhuriyet başsavcılığının uygun gördügüü bir aile yakını refakatçi olarak bulundurulabilir. Açık cezaevi ile çocuk eğitimevi hükümlülerinin kurum dışında yatarak tedavileri, tedavi eden kurumun bulunduğu yerdeki kurumun iç güvenlik görevlileri gözetiminde ve hükümlü koğuşu dışındaki bir bölümde yapılır. ${ }^{[14]}$

$\mathrm{Bu}$ hastanelere gönderilen hükümlülerin başka yerlerdeki hastanelere sevki, sağlık kurulu raporuyla mümkündür. Ancak acil ve yaşamsal tehlikesi bulunması hâlinde, varsa biri hastalığın uzmanı olmak üzere iki uzman hekim tarafindan verilip, başhekim tarafından onaylanan ve hastalığın nedeni, tedavinin hangi nedenle bulunduğu hastanede gerçekleştirilemediği, hastaya nerede ve ne tür bir tedavi gerektiğini açıkça belirten bir rapor yeterlidir. Bu durumda da en yakın ve hükümlü koğuşu bulunan Devlet veya Üniversite Hastanesi tercih edilir. Cumhuriyet Başsavcılıkları aracılığıyla yapılan bildirimler doğrultusunda; 2014 yılı verilerine göre ülkemizde, 336 Devlet Hastanesinde hükümlü koğuşu bulunduğu; bunların yatak kapasitesinin toplam 1184 olduğu belirlenmiştir. ${ }^{[11]}$

5275 sayılı Kanun'un beşinci fikrası ise tutuklu ve hükümlülerin sağlık nedeniyle başka bir ceza infaz kurumuna nakledilmesini düzenlemektedir. Buna göre, kurum idaresi veya hükümlünün talebi üzerine, sağlık nedenleriyle bulunduğu kurumda kalmasının uygun olmadığı, kurum hekiminin önerisi ve en üst amirinin isteği üzerine alınacak sağlık kurulu raporuyla belirlendiği takdirde, hükümlü, cezasının infazı veya en yakın sağlık kuruluşunda tedavisinin yapılabilmesi amacıyla başka kurumlara nakledilebilir. ${ }^{[11,13]}$

Tutuklu ve hükümlülerin hastaneye sevki sırasındaki araç temini ve eşlik edecek personel Ceza ve Tevkif Evleri Genel Müdürlüğü tarafından sağlanırken; 
muayene, tetkik kontrol ve tedavi bedelleri Sağlık Bakanlığı bütçesine konulan ödenekten karşılanmaktadır. ${ }^{[15]}$ Bir tutuklu ve hükümlünün kampüs dışarısında bir hastaneye sevki, çok sayıda personelin görev yaptığı, idari ve mali açılardan karmaşık bir süreçtir.

Bu nedenlere, tutuklu ve hükümlünün muayenesine makul bir zaman ayırmalı, muayene notları ve tedavi kararı özenli bir şekilde, UYAP (Ulusal Yargı Ağı Projesi) sistemine de işlenen, şahsi sağlık dosyasına ayrıntılı olarak not düşülmelidir. Kontrol muayenesi için yeniden çağırılacaksa veya girişimsel bir işlem planlandıysa, tarih net bir şekilde yine sağlık dosyasına yazılmalıdır.

\section{ORTOPEDI VE TRAVMATOLOJI'NIN YERI}

Ortopedi ve Travmatoloji polikliniğine başvuran tutuklu ve hükümlülerin önemli bir kısmı minör travmalar sonrası gelişen ayak bileği, el bileği ve parmak eklemlerinin burkulması gibi şikâyetler ile gelmektedirler. Kırıkların büyük çoğunluğunu da ayağın ve elin küçük kemik kırıkları oluşturmaktadır. Travmalar dışında ise, en sık eklem (özelikle el - el bileği, diz ve ayak - ayak bileği) ağrıları nedeniyle hastaneye başvuru yapılmaktadır. Ülkemizde yapılan bir çalışmada bu bilgileri destekler bir sonuca erişilmiştir. Tutuklu ve hükümlülerin acil servise başvuru nedenleri incelenmiş ve \%15,6'sının spor yaralanmalarına bağlı olduğu ve spor yaralanmalarının acil servise en sık başvuru nedeni olduğu bildirilmiştir. ${ }^{[16]}$ Yapılan bir çalışmada ise cezaevinde gerçekleşen yaralanmalar değerlendirilmiş ve başvuruların \%55'ine yumuşak doku bozukluğu tanısı konulurken, \%28'inin kırık şüphesi ile sevk edildiği bildirilmiştir. ${ }^{[17]}$ Cezaevindeki hastalık çeşitlerini araştıran başka bir çalışmada ise artrit prevalansı $\% 20,5$ olarak belirlenmiştir. ${ }^{[9]}$

Tutuklu ve hükümlülerin tedavisine karar verirken, cezaevinin sosyal ve fiziki koşullarının da kararda etkili olması gerekir. Cezaevinde hastaların çoğunlukla kendi başlarına kişisel bakımlarını yapmaları gerektiği (bakım veren eksikliği) ve uygun fiziki şartların sağlanmasında zorlukların olduğu (klozet tarzında tuvalet yokluğu gibi) bilinmelidir. Bu nedenle, özellikle alt ekstremite problemleri ile gelen tutuklu ve hükümlülerin, eğer tıbbi olarak imkân dâhilinde ise, bir an önce mobilize edilmesini sağlayacak tedavilerin tercih edilmesi uygundur.

Tek başına öz bakımını yapamayan ve başkasının bakımına muhtaç olan hasta tutuklu ve hükümlülerin barındırılması, rehabilite ve tedavilerinin sağlanması amacıyla rehabilitasyon tipi cezaevleri de bulunmaktadır. Sağlık kurullarının ve savcılığın uygun gördüğü durumlarda, tutuklu ve hükümlülerin bu tip cezaevlerine nakli sağlanabilir. Yine, maruz kaldığı ağır bir hastalık veya engellilik nedeniyle, mahkumun ceza infaz kurumu koşullarında hayatını yalnız idame ettiremeyeceği ve toplum güvenliği bakımından ağır ve somut tehlike oluşturmayacağı değerlendirilmişse, cezasının infazı, iyileşinceye kadar Adlî Tıp Kurumunca düzenlenen ya da Adalet Bakanlığınca belirlenen ve tam teşekküllü hastanelerin sağlık kurullarınca düzenlenip Adlî Tıp Kurumunca onaylanan bir raporun varlığı halinde, Cumhuriyet Başsavcılığınca birer yıllık dönemlerde geri bırakılabilir.

Hükümlülerin, bunlara ek olarak, Cumhurbaşkanlığı affindan yararlanma amacıyla Cumhuriyet başsavcılığına direkt olarak başvurma hakları da bulunmaktadır. Başvurusunu direkt olarak yaptıktan sonra; hastanın tam teşekküllü bir hastaneye sevki sağlanarak ve hakkında ayrıntılı bir muayene sonucu gönderilecek rapor ile birlikte Adli Tıp Kurumu'nca tekrar muayenesi yapılarak, Türkiye Cumhuriyeti Anayasası'nın 104. Maddesine göre sakatlık ve kocama halinin teşkil edip etmediği cevaplanmaktadır. Ceza infaz tehiri bulunan hükümlülerin üçer aylık dönemlerle tekrar muayene edilerek raporların süresi uzatılabilir ya da infaz tehiri kaldırılabilir. ${ }^{[11]}$

Ülkemizde tutuklu ve hükümlüler arasındaki hastalık yükü ve hastane başvuruları ile ilgili yapılan çalışmalar son derece yetersizdir. Cezaevlerinde yapılacak keşif çalışmaları, mevcut alt yapı ve insan gücünün doğru şekilde yönlendirilmesini, daha etkili ve verimli bir sağlık hizmeti verilmesini sağlayacaktır. Tutuklu ve hükümlülerin Acil Servise ve Polikliniklere başvuru nedenlerinin önemli bir kısmı kas iskelet sistemi hastalıklarından dolayıdır. Ortopedi ve Travmatoloji uzmanları, bu özel hasta grubunun tedavisinde önemli bir paydaştır ve tedavi kararları verilirken hasta grubunun özel durumu muhakkak göz önünde bulundurulmalıdır. Tutuklu ve hükümlüler tedavi sonrasında bir an önce öz bakımını yapabilecek ve ihtiyaçlarını karşılayabilecek duruma gelebilmelidir.

\section{KAYNAKLAR}

1. Shalit M, Lewin MR. Medical care of prisoners in the USA. Lancet 2004;364(Suppl 1):34-5. Crossref

2. Vetter C, Robert-Tissot L, Cottagnoud P, Stucki A. [Working under pressure]. Praxis (Bern 1994) 2008;97(8):437-42. Crossref

3. Watson R, Stimpson A, Hostick T. Prison health care: a review of the literature. Int J Nurs Stud 2004;41(2):119-28. Crossref

4. Butler T, Kariminia A, Levy M, Murphy M. The self-reported health status of prisoners in New South Wales. Aust N Z J Public Health 2004;28(4):344-50. Crossref

5. Harel N, Moskovitch JT, Weiland TJ, Augello MR. Review article: Common emergency department presenting complaints of prisoners: A systematic review. Emerg Med Australas 2019;31(2):183-92. Crossref 
6. Stone J, Fraser H, Lim AG, Walker JG, Ward Z, MacGregor L, Trickey A, Abbott S, Strathdee SA, Abramovitz D, Maher L, Iversen J, Bruneau J, Zang G, Garfein RS, Yen YF, Azim T, Mehta SH, Milloy MJ, Hellard ME, Sacks-Davis R, Dietze PM, Aitken C, Aladashvili M, Tsertsvadze T, Mravík V, Alary M, Roy E, Smyrnov P, Sazonova Y, Young AM, Havens JR, Hope VD, Desai M, Heinsbroek E, Hutchinson SJ, Palmateer NE, McAuley A, Platt L, Martin NK, Altice FL, Hickman M, Vickerman P. Incarceration history and risk of HIV and hepatitis $C$ virus acquisition among people who inject drugs: a systematic review and meta-analysis. Lancet Infect Dis 2018;18(12):1397-409. Crossref

7. Ahmed R, Angel C, Martel R, Pyne D, Keenan L. Access to healthcare services during incarceration among female inmates. Int J Prison Health 2016;12(4):204-15. Crossref

8. Harris JB, Siyambango M, Levitan EB, Maggard KR, Hatwiinda S, Foster EM, Chamot E, Kaunda K, Chileshe C, Krüüner A, Henostroza G, Reid SE. Derivation of a tuberculosis screening rule for sub-Saharan African prisons. Int J Tuberc Lung Dis 2014;18(7):774-80. Crossref

9. Rosen DL, Hammond WP, Wohl DA, Golin CE. Disease prevalence and use of health care among a national sample of black and white male state prisoners. J Health Care Poor Underserved 2012;23(1):254-72. Crossref

10. World Prison Brief-Prison brief data of Turkish Ministry of Justice 2018. Erişim: https://www.prisonstudies.org/country/turkey
11. Türkiye Büyük Millet Meclisi İnsan Haklarını İnceleme Komisyonu, Ceza İnfaz Kurumlarında Hükümlü ve Tutuklulara Sunulan Sağlık Hizmetleri Hakkında İnceleme Raporu; 2015. Erişim: https://www.tbmm.gov.tr/komisyon/insanhaklari/ docs/2015/saglik_hizmetleri_hakkinda.pdf

12. Ceza İnfaz Kurumlarının Yönetimi ile Ceza ve Güvenlik Tedbirlerinin İnfazı Hakkında Tüzük; 2006. Erişim: https:// www.mevzuat.gov.tr/MevzuatMetin/2.5.200610218.pdf

13. 5275 sayılı Ceza ve Güvenlik Tedbirlerinin Infazı Hakkında Kanun; 2004. Erişim: http://www.ceza-bb.adalet.gov.tr/ mevzuat/5275.htm

14. Ceza İnfaz Kurumlarının Yönetim, Dış Koruma, Hükümlü ve Tutukluların Sevk ve Nakilleri ile Sağık Hizmetlerinin Yürütülmesi Hakkında Protokol; 2017. Erişim: http://www.cte. adalet.gov.tr/Resimler/Dokuman/592019112913p47.pdf

15. Ceza İnfaz Kurumlarına Gönderien Ödeneklerin Kullanımı Genelgesi; 2006. Erişim: https://www.adalet.gov.tr/ Genelgeler/genelge_pdf/47.pdf

16. Koc B, Tutal F, Urumdas M, Ozkurt Y, Erus T, Yavuz A, Kemik $O$. The preliminary experience in the emergency department of a newly opened penitentiary institution hospital in Turkey. N Am J Med Sci 2014;6(9):460-5. Crossref

17. Ludwig A, Cohen L, Parsons $A$, Venters $H$. Injury surveillance in New York City jails. Am J Public Health 2012;102(6):110811. Crossref 